JOURNAL OF SECURITY AND SUSTAINABILITY ISSUES

ISSN 2029-7017 print/ISSN 2029-7025 online

2019 March Volume 8 Number 3

http://doi.org/10.9770/jssi.2019.8.3(18)

Scopus

\title{
MIGRATION CULTURES AND THEIR OUTCOMES FOR NATIONAL SECURITY
}

\author{
Inna Gryshova', Boris Kofman², Olga Petrenko \\ ${ }^{1}$ Jiangsu Normal University, 101 Shanghai Rd, Tongshan Qu, Xuzhou Shi, 221100, Jiangsu Sheng, China \\ ${ }^{2}$ Institute of Legislation of the Verkhovna Rada of Ukraine, Nesterovsky per. 4, 04053, Kiev, Ukraine \\ ${ }^{3}$ Odessa State Agrarian University, Panteleimonovskaya str. 13, 65000 Odessa, Ukraine

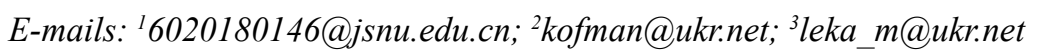

Received 20 November 2018; accepted 15 January 2019; published 30 March 2019.

\begin{abstract}
International migration is a functional component of modern societies, both wealthy and poor. In a way, one can see that migration solves the unequal distribution of people and opportunities. Despite the political pressure to control immigration, almost all changes in politics have broadened the scope of legal immigration to allow for settlement by refugees, farm workers (in case of urbanrural migrations), "illegal" immigrants with long-term residence in the country, and workers in great demand to move around freely. Our main research objective is to demonstrate, using the available data as well as the analysis of the metadata and the research literature, that migration, especially labour migration, has a narrow connection with the issues of national security. Large outflows and inflows of people might bring about security threats linked to organized crime, terrorism and the spread of radical ideas. Moreover, migration is responsible for the brain drain of young and well-educated people who are searching for higher wages and better opportunities abroad depriving their own home country of valuable human capital. Our paper analyses the phenomenon of international migration perceived from the angle of migration culture that goes hand in hand with recent globalization trends all around the world. We come to a solid conclusion that migration policy should be treated as an important element in establishing well-ballanced national security policy in the globalized world. It might be of a particular interest for the migration scholars, labour market economists and stakeholders and policy-makers dealing with the issues of national security, public and migration policies, as well as sustainable economic development.
\end{abstract}

Keywords: migration, security, labour market, cultural aspects, sustainable development

Reference to this paper should be made as follows: Gryshova, I., Kofman, B., Petrenko, O. (2019). Migration cultures and their outcomes for national security. Journal of Security and Sustainability Issues, 8(3), 521-530. http://doi.org/10.9770/jssi.2019.8.3(18)

JEL Classifications: F22, F24, H56

Additional disciplines political sciences; sociology; cultural studies; international relations

\section{Introduction}

International migration is an essential part of human history. The process of leaving one country of economic and social incentives or being driven out (or even chased out) by infavorable conditions at home (famous "pull" and "push" factors) has always been going hand in hand with human mobility and pursuing economic incentives. International migration has been on the rise in the previous decades and has evolved into a worldwide phenomenon. It has been an essential part of the history of humankind for centuries but the simplification of travel and the economic development in the new colonies overseas made it a very important element of the economic sustainable development. The mass migration one can witness today is not a state of emergency but the start of a new reality. The culture of migrations has become an integral part of the world's culture and is not perceived as a consistent part of the human civilization being promoted in popular culture, films, books, and TV series (Cohen and Sirkeci, 2011; or Issa, 2016). 
The culture of international migration is a part of both national and global security challenges, both directly and because of the effects of instability, such as Syrian and Iraqi conflicts, which increase mass migration and trafficking. In the same time, the ageing of the population in most of the developed Western economies is understood as a national challenge with a proposed way of tackling this issue by the means of the targeted immigration policies as well as strengthening the integration policies for preventing the emergence of extreme right-wing extremists, xenophobia and nationalism, which can put the social coherence at risk. As developed societies are ageing, and in some cases shrinking, they are increasingly turning to international migration to support economic growth, with a focus on knowledge-based activities. A significant change in the global demographic region, which was discussed, is China's move from a demographic dividend to a country with a population deficit, and from an economy based on low - cost labour to a higher salary due to the development of high-tech and scientific industries (Wang, 2016; Cheung, 2017).

Migration cultures as we know them nowadays are being shaped up thanks to the ongoing globalization (Timur, 2000; Bilan and Strielkowski, 2016; Škuflić et al. 2018; Todorov et al. 2018; Lialina 2019). Traditionally seen as an economic phenomenon related to the growth of the global market, globalisation and its effects have begun to affect every aspect of social life, from culture to crime, finance and religion (Ali, 2007). Nowadays, globalisation is characterised by four major trends: rising commodity and human flow, expansion and diversification of financial activity, communication development of networks, knowledge and relationships, and growing differences. At the moment globalization is during its summit. Regarded as one of the benefits, it has led to the creation of employment opportunities that were numerous. In the real sense, it has not been able to reduce poverty.

In addition, globalization enhances the movement of goods, services and people across borders, as migrants benefit economies of reception countries through their research, while the implementation of climate change and mitigation measures promote sustainable development in domestic countries. In today's burgeoning economic areas such as the Persian Gulf states, China and India, the private sector needs to move beyond the short-term profit focus and may require putting more emphasis on environmental and social issues in business models to achieve sustainable returns.

United States has always been a migration country which shaped up its culture and its unique identity (Hoschle et al., 2015). The well-known "melting pot" iis however suffering some leaks due to racial tensions and economic situation. Nevertheless, it is the European Union (EU) that is one of the most effected areas in terms of migration inflows nowadays. Its considerable wealth as well as its social and welfare approach constitute a target for many migrants and asylum seekers from numerous countries. EU faces many issues connected to international migration and lots of them are not easy to be resolved or mitigated (Zaiceva, Zimmermann, 2008; De Luna Gallardo, 2016).

Our paper aims at studying the phenomenon of migration cultures and their impact on national security (defined as a given country's economic and national security). We take the example of recent developments in the European Union to make our point. Moreover, we also focus on the issue of welfare and social aspects that are very important in today's European Union.

We analyse the vast body of literature dealing with migration worldwide and in the European Union (EU). In addition, we make a particular focus on the Turkish and Ukrainian migrations in Europe as two valuable examples of unceprecedented migration flows that carry all the characteristics of the cultural and economic issue that might shape up European security and sustainable economic development.

\section{Literature review}

It is quite obvious that there is a clear and distinguishable link between such issues as migration and war conflicts, corruption, organised crime or demographic changes. Global serious issues such as military and civil war conflicts, world poverty, terrorism and organised crime constitute global and transnational threats 
to national security. Moreover, they are capable of increasing migration flows, which can in turn lead to the increase in illegal migration, human trafficking, modern slavery, or brain drain (see Estevens, 2018; Passiatore et al., 2019).

A significant reduction in the number of immigrants from any given country should be viewed as an important element in the security of this country (Faist, 2000). Within this context, it is important to limit the process of economic migration among the group of migrants represented by young and educated people (Mertens et al., 2019). The brain-drain of the outflow of the potential personnel and valuable work capital might be perceived as an irreversible loss by the country's economy, defence sector and armed forces (Kalyugina et al., 2015; Lazaridis, 2016).

Nowadays, immigration policy in most developed Western countries is in the middle of fiscal and political debates centring around many of the challenges and resources (Carling, Schewel, 2018). The governments have policies geared toward enhancing education for immigrants. The protests are unofficially permitted to continue though it had no role in it. A great deal of people came to be contingent on the government or charities to furnish them with food.

An interesting aspect worth studying is migration and remittances. Remittances constitute a value comparable to international aid and are often a considerable injection into the less-developed economies of sending countries (Stojanov et al., 2011; Rausser et al., 2018). Transferring money or goods from abroad to support their families and friends is an efficient tool of fostering economic situation at home, however it can also become a way of financing terrorism and organized crime (Strielkowski et al., 2017).

Creative people from all around the world are migrating to take part in the expanding medium. Countries target their net income to be produced by individuals. Some countries allow restrictions on movement. Every country is able to somehow, identify with its own culture, despite the fact that it is a fact diverse. Not every nation in the world is on equal footing in conditions of technological improvement and power. Thence, there is a difference between legal and illegal immigration (Horváth, 2008).

One would probably agree that migration is often a political issue, especially when it has to do with illegal immigration. Although migration is viewed by people from various perspectives, objective advantages are quantifiable and assessable. Even illegal immigration has a positive impact on the average taxpayer. Various considerable and massive immigration flows that happened throughout history (e.g. Irish and Cuban immigration to the United States, Russian immigration to Israel, Polish migration to the United Kingdom, etc.) has left an enduring impression the cultures of the origin and target countries.

\section{Research objectives and methodology}

Economists have recently recognised that, in addition to direct interaction with markets, prices and revenues, other social and cultural non-market interactions can also be a key factor in the social and economic integration of immigrants. For example, specific cultural patterns of immigrant groups can have a significant impact on their performance in the labour market. More generally, social scientists have made great efforts to ensure that immigrant integration patterns can radically change the design and political economy of public policy in a host society. Thence, cultural diversity brought about by migration can in fact influence the sense of community and social solidarity, which are the main pillars of democratic system welfare.

The research aim of the present study is to study the interconnectedness between the international migration (including the labour migration and asylum migration) and the threats to national security using the example of the European Union. Hence, we can formulate the research question as expressed by the two following research hypotheses:

H1: There is a link between migration-embedded cultures and economic and social prosperity in the receiving countries. 
H2: International migration has a significant impact on the country's security and thence should be treated with special targeted governmental policies and tools.

On the basis of standard measures of social and economic performance, place of residence and inter-marriage, children and grandchildren of the first wave of immigrants are almost completely integrated into the new country's society. However, recent immigrants and their offspring, combined with other reform groups, also play a major role in the expansion of democracy in the target country society. For example, immigration, in particular clandestine immigration, is higher in the United States than in most other industrial countries, but the underlying dynamics are widespread for almost all industrial companies (Hirschman, Mogford, 2009).

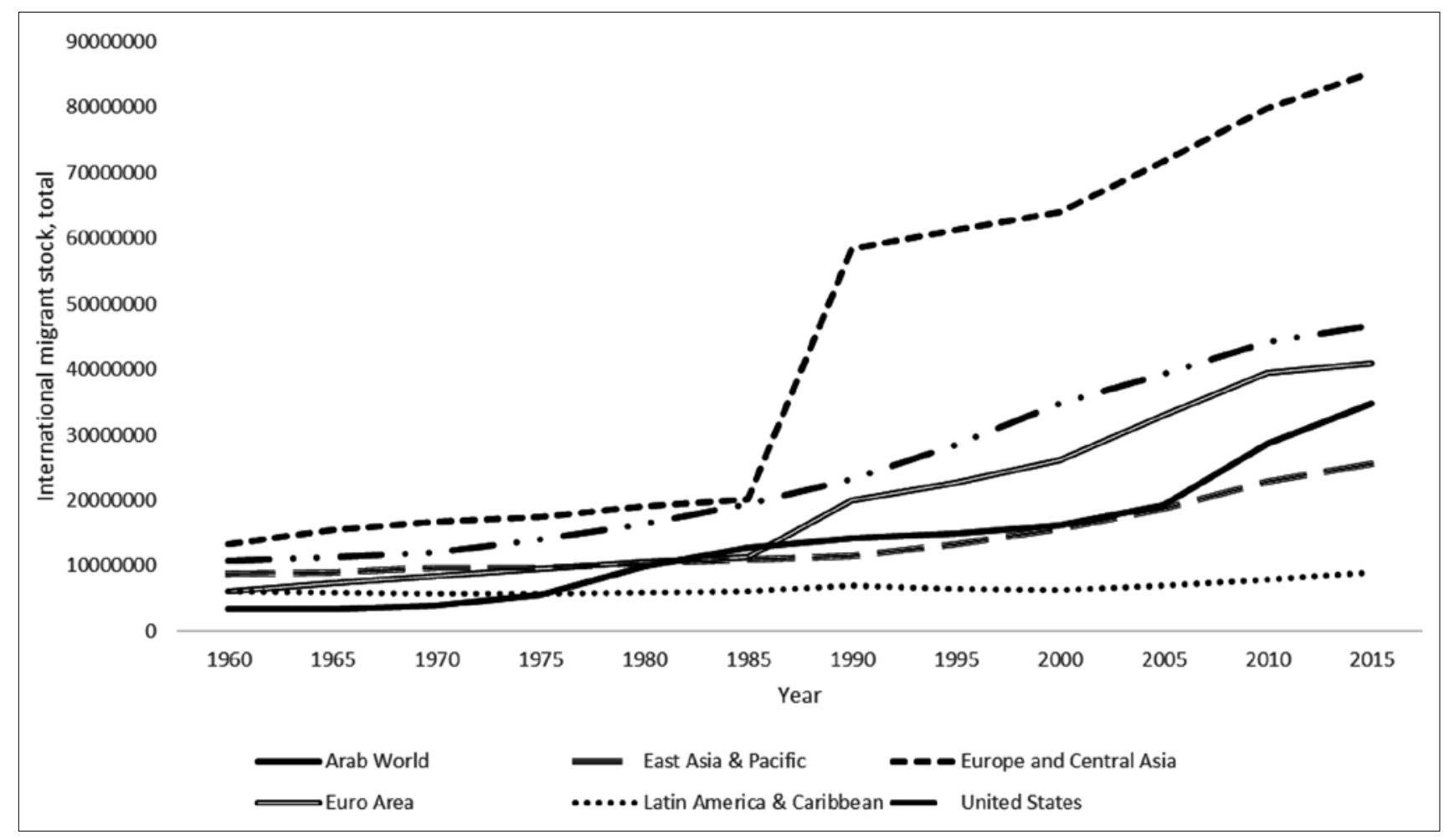

Figure 1. International migration dynamics

Source: World Bank (2019)

One specific groups of migrants in asylum seekers. The case of asylum migration became notoriously known thanks to mass media that monitored the influx of hundreds of thousands of migrants from war-torn Syria seeking refuge in European Union countries, most frequently Germany (Yazgan et al., 2015). The "way of Syrian asylum seekers" became a part of the pop culture and is referred to very often.

Many people tend to think that asylum seekers mean a financial and security burden for the target (or host) country. While the issue of their impact of national security is arguable, many scientists found no proof of the financial burden and negative economic impacts on the host economy. For example, D'Albis et al. (2018) assess the fiscal and economic effects of inflows of asylum seekers into Western Europe with the information in 1985 to 2015 and estimating the macroeconomic consequences of structural shocks and policies. They discovered that inflows of asylum seekers did not deteriorate host nations' financial performance or fiscal balance because of the increase in spending brought on by asylum seekers is paid for by a rise in tax revenues.

Figure 1 above shows international migration dynamics. The Figure covers the period from 1960 to 2015 and provides the data for several clustered regions of the world. One can clearly see that the largest increase in the total stock of international migrants can be attributed to Europe and Central Asia (with Europran Union countries representing the largest share in this rapid and shart upward slope). 
Two interesting cases of migration cultures can be analysed here for better comparison: Turkish migration and Ukrainin migration in the European Union. Both are targeted at the most developed EU countries and both represent valuable example of distinct migration cultures and possible economic and security threats.

Turkish migration to Europe started in the 1960s with Turkish "guest workers" or "gastarbaiters" being invited by the governments of the Federal Republic of Germany or the Netherlands who faced labour shortages (especially in low-paid manual professions). The Turkish government gladly responded to that call and thousands of Turkish workers started pouring into the EU countries. Within several decades, the Turkish diaspora in the EU has reached about 3-4 million people, most of whom are second-generation EU citizens of Turkish origin. Glazar and Strielkowski (2010), Strielkowski and Glazar (2014), or Sirkeci and Cohen (2016) describe the antagonisms and the conflicts that have been subjected to the issues of migration and integration. The issue of Turkish migration (possible incoming migration flows after the eventual free movement of labour granted to Turkey by the European Union) became the bargaining chip in the decades-long negotiations about Turkish EU accession that has never materialized).

On the other hand, Ukrainian migration in Europe is quite similar to Mexican migration into the United States (a special case, since migration is getting more diverse including the majority of the country involved in it with multiple U.S. destinations getting more dispersed and targeted by Mexican migrants) (see Kandel, Massey, 2002). One would probably agree that Ukrainian migration in the EU (and in some countries where it is particularly abundant, such as Poland, the Czech Republic, Italy, or Spain) signifies a significant occurrence and special implications for the labour market and national security (see Iglicka, Weinar, 2008; Strielkowski, Weyskrabova, 2014; Ambrosetti et al., 2014; Čajka et al., 2014; Ducháč et al., 2015; Strielkowski et al., 2015; or Van Mol et al., 2018). Moreover, Sanderson et al. (2014) focused on the construction sector, because of its significance in the process of new destination creation in the Czech Republic, also found that the Ukrainian migration into the Czech Republic is firmly channelled along occupational lines linking the Ukrainian and Czech construction sectors.

The two examples discussed above are very relevant for the current situation in the EU which should look to facilitate the UK's exit from the European Union (the so-called "Brexit). In the end, EU has to be skeptical of a policy void after Brexit and the security vacuum it will cause. At the same time, it would need to stay willing and able to cooperate on areas of interest.

Britain and France, in addition to the EU collectively, will need to invest efforts to control the rest of the challenges in the area. Europe is in the midst of a very difficuakt economic and political situation at the moment. Moreover, $t \mathrm{t}$ is in the middle of the largest refugee crisis since World War II. Therefore, EU will need to consolidate its approaches to migration and to steady its migration policies in order to deal with the growing number of migrants from the third countries, as well as with the UK citizens who are now residing in the EU countries (according to some estimates, there are about 2-3 million UK citizens in various EU countries at the moment of Brexit).

The processes of globalisation are not new or a recently invented brands, however. Though these forms of support attempt to alleviate a few of the issues related to a scarcity of growth they are often short-term fixes. Thus, while there are numerous kinds of globalisation, one of its most vital aspects is its dependence on free commerce. All of them serve to produce contacts with pieces of the entire world unobserved or normal and a routine' part of life.

The racial and cultural composition of contemporary societies have dramatically changed in the last couple of decades since (and thanks to) a result of migration. It is very important to utilise present research structures and tools to encourage the evolution of a research agenda on migration and welfare, along with to find support for the evolution of dedicated research commissions on wellness and migration at multiple levels so as to harness evidence to induce policy-making and programme creation. This approach enables us to isolate the part of the correlation between diversity and monetary growth that's due to the effect of diversity 


\section{Results and discussions}

Our results show that migration is increasing worldwide, and migrants are increasingly diverse in terms of social and cultural characteristics. New advances in information and transport technology are increasing the number of temporary, repetitive and circular migration

It appears that globalisation, defined as the spread of cross-border and transnational networks, has changed the context of migration. Globalisation is not only an economic phenomenon: the influx of capital, goods and services cannot happen without a parallel flow of ideas, cultural products and people.

Scientists must focus on the growing importance of migration as key figures for the protection of culture and society in the present, not only by understanding the trends and changes, the consequences and differences in behaviour and experience of migration in the past.

Migration historians also examine the migrant agency in migration processes (such as motivation, networking, impact on structures such as family and state) under certain structural limitations. It is important here that the whole range of migration processes in a given field, including the interaction between all identifiable patterns of migration and their specific socio - economic, demographic and political position.

One very pressing issue that coincides both with migration culture in Europe and its security and economic sustainability is that of refugees and asylum seekers. It appears that not all asylum seekers will end up as refugees granted residence in the EU. It often happens that the terms asylum seeker, refugee and migrant are many times used interchangeably which results in confusion with regard to the status of particular individuals. Those countries which might be in warfare could technically be announced safe in case the war does not undermine each and every region and most of its citizens. They must get a way to move forward in these conditions. Thus, many neighbouring states beyond the EU that do not have the capacity to supply the protection and support required to refugees would be legally made to take asylum seekers back from the European territory.

The worldwide community should make sure about where the genuine crisis is. You could also locate local nonprofit organizations in your area which are helping immigrants and also ask their own referrals. Once it seems the EU leaders have started to grapple with the specific situation in a realistic fashion, much damage is already done. Leaders in Germany and other European countries say they are ready to award asylum to valid refugees from countries including Syria, Iraq, or Eritrea. However, they are issuing more rigorous warnings they are going to reject a number of the financial migrants flowing over their boundaries.

The European migration debate is not new, and it can look upon the examples of other nations like the United States, Argentina, or Brazil which always comprised large immigrant populations. Commitment to certain values and ideas is paramount, citizenship in these countries is based not on ethnic grounds, but on another kind of identity. But the nation is defined ethnicity, heritage, and a language. This raises important questions for nations that don't have long traditions of immigration. How long can an immigrant need to live in Germany becoming a German? Can someone be without speaking French? Should immigrants be forced to take? Indeed, matters are a factor in Europeans reaction to migration.

Fear of immigration stood behind the success of several nationalist or even right-wing political parties in various European Union countries. Some of those politicians or parties used unemployment and crime as their political slogans blaming migration for them. Several subsequent European Union enlargements that started in the 1980 have streamlined internal migration policy in EU Member States. As a result, EU citizens can now move relatively freely across national borders inside the European Union. The Schengen agreement allows this and also ensures the exchange of security information on border violators or extradited third country citizens.

However, even inside the EU itself, Member States carry out inconsistent policies concerning the third country nationals (aka citizens of non-EU nations). The number of immigrants from outside the EU varies with years 
and territories. This implies the fact that unemployment rates caused by the recent financial crisis had the effect of stripping migrants of their immigration status. In most EU countries, including Sweden, Britain, Denmark, or Italy, just to name a few, migration became a central issue in elections. France, a second most important EU economy has also followed suit.

The examples of the above troubling issues are quite numerous: for example, Dutch new Interior Minister proclaimed that he wanted to get rid of the most of the country's controversial immigration policies. The Interioir Minister wants to re-centralize decision making on naturalization in order to keep one policy used for all immigrants. Nevertheless, in 2013, former French Prime Minister Francois Fillon has spoken out against what he believed was an excess of immigrants in France and the financial difficulties and lack of federal cohesion in the country it caused in his opinion. These political steps are against the accepted beliefs that migration brings in young talents, reduces the costs of labour and generally helps the economic growth and development. However, the political side in the EU often outweights the economic (and rational) one. Unfortunately, migration is one of these cases.

Furthermore, there is an issue of sustainable economic and balanced development that migration might ensure. One would probably agree that for sustainability to turn into a reality, humanity should earn a quantum shift in consciousness. It is a broad topic that describes whether a practice can be done indefinitely without harming people or society or the environment in such a way that the practice must be stopped. It is not a passing fad or a marketing gimmick, it is a worldwide movement that is changing the way we do business. It is a great way to improve efficiency. Building sustainability is an increasing industry in many developed nations, like the United States or the European Union. Clearly, without the load of having to manage the menace of terrorism, global financial growth and development might be significantly greater. Sustainable development does not mean raising the whole world as individuals to the identical degree of consumption.

\section{Conclusions}

Overall, our results show that the European Union migration policies demands initiative, but inclusion is necessitated by certainty. The government today does not possess a crystal-clear plan of activities in the field of market development or migration policy generally.

We find that the massive migration of people around the world is a characteristic feature of the modern world, and the European Union has long been at the forefront of such a complex, global dynamic. In fact, immigration is a key feature of the way Europeans see their national history and the evolution of European identity - an important part of the history of what it means to be European.

Our research showed that there is interconnectedness between the international migration, labour migration and asylum migration, and the threats to country's economic and national security in the European Union Member States. Furthermore, it becomes apparent that there is a link between migration-embedded cultures and economic and social prosperity in the receiving countries represented by the EU Member States.

With regard to refugee and immigration policy, it is important to ensure a fair European tax division, while at the same time developing viable solutions through dialogue with the countries of origin, the countries of origin and transit. Security threats combine migration with drug trafficking, but the migration is self-examined, as it can pose public and national security threats.

Internal migration to the EU occurs for a variety of reasons, such as response to political conflicts, environmental or economic pressures, which can create new challenges for the host and target countries. Migration problems are usually investigated according to feedback, as demographic changes, a shortage of natural resources, conflicts or poverty can lead to increasing migratory pressure.

While scientists, civil society groups, governments and international NGOs are studying, hiding and discussing 
the movements of millions of people every year, migration in European Union has long and well-studied history that can help formulate healthy policies at local, national and international level. However, as the number of migrants increased, several EU countries began to address certain groups of immigrants as undesirable and, in some cases, threats to social welfare and state security. This is an adverse effect of migration when favourable economic opportunities might be eroded and flowed to specific places because of specific economic conditions.

Migration and welfare policy and priority setting processes need to be directed by multisectoral and interdisciplinary believing as a means to attack the determinants related to the wellbeing of both internal and cross-border migrants. Integration is a procedure that involves social, economic, cultural and mental domains of people's lives. Worldwide development or development that is worldwide is a broad notion concerning level of development on a global scale. An intriguing method of seeing growth in Third World countries is via modernization. Every development project involves a part of education as development by its very nature demands a shift in how people live.

All in all, we might conclude that international migration comes through as a significant factor for any given country's security and therefore special care and attention as well as targeted economic, social and welfare policies should be attributed for treating it as such. It is obvious that migration contributes significantly to the trend of urbanisation, as people are looking for better social and economic opportunities and away from the deterioration of the environment. Migration and climate change objectives to be integrated into national development and poverty reduction programmes, including risk reduction and crisis planning, as well as agricultural policies and practices aimed at increasing resistance. Host countries can maximize the potential of migrants by engaging productively, educating, developing opportunities and integrating opportunities into society.

Last but not least, we should remark that it seems important to build upon the unique European culture of migration and use it to tackles the economic and security threats that EU faces today with such serious threats as the impending Brexit that might cause unexpected changes to the geopolitical situation not only at the European continent but also worldwide.

\section{References}

Ali, S. (2007). 'Go west young man': The culture of migration among Muslims in Hyderabad, India. Journal of Ethnic and Migration Studies, 33(1), 37-58. https://doi.org/10.1080/13691830601043489

Ambrosetti, E., Cela, E., Strielkowski, W., \& Abrhám, J. (2014). Ukrainian Migrants in the European Union: a Comparative Study of the Czech Republic and Italy. Sociologija i Prostor, 52(2), 141-166. . https://doi.org/10.5673/sip.52.2.2

Bilan, Y., \& Strielkowski, W. (2016). Migration in post-transition economies: immigration surplus in Visegrad group countries. International Journal of Trade and Global Markets, 9(2), 182-196. https://doi.org/10.1504/IJTGM.2016.076310

Čajka, P., Jaroszewicz, M., Strielkowski, W. (2014), Migration Incentives and Flows between Belarus, Moldova, Ukraine and the European Union: a Forecasting Model. Economics and Sociology, 7(4), 11-25. https://doi.org/10.14254/2071-789X.2014/7-4/1

Carling, J., \& Schewel, K. (2018). Revisiting aspiration and ability in international migration. Journal of Ethnic and Migration Studies, 44(6), 945-963. https://doi.org/10.1080/1369183X.2017.1384146

Cheung, N. W. (2017). Gender, Victimization, and Adolescent Psychological Health in the Context of Migration: Evidence from China. Youth \& Society, 0044118X17734232. https://doi.org/10.1177/0044118X17734232

Cohen, J. H., \& Sirkeci, I. (2011). Cultures of migration: The global nature of contemporary mobility. University of Texas Press.

d'Albis, H., Boubtane, E., \& Coulibaly, D. (2018). Macroeconomic evidence suggests that asylum seekers are not a "burden" for Western European countries. Science Advances, 4(6), eaaq0883. https://dx.doi.org/10.1126/sciadv.aaq0883

De Luna Gallardo, G., Korneeva, E., \& Strielkowski, W. (2016). Integration of migrants in the EU: lessons and implications for the EU migration policies. Journal of International Studies, 9(2), 244-253. https://doi.org/10.14254/2071-8330.2016/9-2/19

Ducháč, T., Strielkowski, W., \& Matušková, A. (2015). Labour Market Restrictions and Migrations in the EU: A Case of Ukranian 
Migration. Romanian Journal of European Affairs 15(1), 23-34.

Estevens, J. (2018). Migration crisis in the EU: developing a framework for analysis of national security and defence strategies. Comparative Migration Studies, 6(1), 28. https://dx.doi.org/10.1186\%2Fs40878-018-0093-3

Faist, T. (2000). Transnationalization in international migration: implications for the study of citizenship and culture. Ethnic and Racial Studies, 23(2), 189-222. https://doi.org/10.1080/014198700329024

Glazar, O., Strielkowski, W. (2010). Turkey and the European Union: Possible Incidence of the EU Accession on Migration Flows. Prague Economic Papers, 3, 218-235. https://doi.org/10.18267/j.pep.373

Hirschman, C., \& Mogford, E. (2009). Immigration and the American industrial revolution from 1880 to 1920. Social Science Research, 38(4), 897-920. https://doi.org/10.1016/j.ssresearch.2009.04.001

Horváth, I. (2008). The culture of migration of rural Romanian youth. Journal of Ethnic and Migration Studies, 34(5), 771-786. https:// doi.org/10.1080/13691830802106036

Hoschle, F., Strielkowski, W., \& Welkins, E. (2015). Spatial segregation of immigrants in US cities: evidence from the United States Census. Theoretical and Empirical Researches in Urban Management, 10(1), 5-13.

Iglicka, K., \& Weinar, A. (2008). Ukrainian Migration in Poland from the Perspective of Polish Policies and Systems' Theory. Journal of Immigrant \& Refugee Studies, 6(3), 356-365. https://doi.org/10.1080/15362940802371580

Issa, T. (ed.). (2016). Alevis in Europe: Voices of Migration, Culture and Identity. Londion: Routledge.

Kalyugina, S., Strielkowski, W., Ushvitsky, L., \& Astachova, E. (2015). Sustainable and secure development: facet of personal financial issues. Journal of Security \& Sustainability Issues, 5(2), 297-304. https://doi.org/10.9770/jssi.2015.5.2(14)

Kandel, W., \& Massey, D. S. (2002). The culture of Mexican migration: A theoretical and empirical analysis. Social Forces, 80(3), 9811004. https://doi.org/10.1353/sof.2002.0009

Lazaridis, G. (2016). Security, insecurity and migration in Europe. London: Routledge

Lialina, A. (2019). Labor market security in the light of external labor migration: new theoretical findings. Entrepreneurship and Sustainability Issues, 6(3), 1105-1125. http://doi.org/10.9770/jesi.2019.6.3(11)

Mertens, S., Standaert, O., d'Haenens, L., \& De Cock, R. (2019). Diversity in Western countries: journalism culture, migration integration policy and public opinion. Media and Communication, 7(1), 66-76. https://doi.org/10.17645/mac.v7i1.1632

Passiatore, Y., Pirchio, S., Carrus, G., Maricchiolo, F., Fiorilli, C., \& Arcidiacono, F. (2019). Intercultural practices and inclusive education in Europe: can migration be a resource for individual and societal development? European Journal of Psychology of Education, 34(1), 209-224. https://doi.org/10.1007/s10212-017-0360-y

Rausser, G., Strielkowski, W., Bilan, Y., \& Tsevukh, Y. (2018). Migrant remittances and their impact on the economic development of the Baltic States. Geographica Pannonica, 22(3), 165-175. https://doi.org/10.5937/gp22-16988

Sanderson, M., Strielkowski, W., Hluštíková, K. (2014). Ukrainian labour migration in the Czech Republic: Brain-Drain and the existence of structural channels. Politicka Ekonomie, 62(4), 542-559. https://doi.org/10.18267/j.polek.968

Sirkeci, I., \& Cohen, J. H. (2016). Cultures of migration and conflict in contemporary human mobility in Turkey. European Review, 24(3), 381-396. https://doi.org/10.1017/S1062798716000119

Škuflić, L.; Krpan, M.; Žmuk, B. (2018). Migration and the economic crisis in the European Union member states: cluster analysis. Entrepreneurship and Sustainability Issues, 6(2), 979-1000. https://doi.org/10.9770/jesi.2018.6.2(34)

Stojanov, R., Strielkowski, W., \& Drbohlav, D. (2011). Labour migration and remittances: current trends in times of economic recession. Geografie, 116(4), 375-400.

Strielkowski, W., \& Glazar, O. (2014). Turkish migration in Europe: EU accession and migration flows. Migration Letters, 11(2), 245257. https://doi.org/10.33182/ml.v11i2.242

Strielkowski, W., \& Weyskrabova, B. (2014). Ukrainian Labour Migration and Remittances in the Czech Republic. Tijdschrift voor economische en sociale geografie, 105(1), 30-45. https://doi.org/10.1111/tesg.12052

Strielkowski, W., Hluštíková, K., Malynovska, O., \& Horváthová, Z. (2015). Ukrainian migration in the EU: a comparative analysis of 
migration and remittence behaviour. Geografie, 120(3), 372-396.

Strielkowski, W., Šperková, L., \& Jacek, B. (2017). Migration and Remittances Nexus: Economic Implications and Analysis. Amfiteatru Economic, 19(46), 771-789.

Timur, S. (2000). Changing trends and major issues in international migration: An overview of UNESCO programmes. International Social Science Journal, 52(165), 255-268. https://doi.org/10.1111/1468-2451.00257

Todorov, G.N., Kalinina, A.V., Rybakova, A.I. (2018). Impact of labour migration on entrepreneurship ecosystem: case of Eurasian Economic Union. Entrepreneurship and Sustainability Issues, 5(4), 992-1007. http://doi.org/10.9770/jesi.2018.5.4(20)

Van Mol, C., Snel, E., Hemmerechts, K., \& Timmerman, C. (2018). Migration aspirations and migration cultures: A case study of Ukrainian migration towards the European Union. Population, Space and Place, 24(5), e2131. https://doi.org/10.1002/psp.2131

Wang, L. K. (2016). The Benefits of in-betweenness: return migration of second-generation Chinese American professionals to China. Journal of Ethnic and Migration Studies, 42(12), 1941-1958. https://doi.org/10.1080/1369183X.2016.1139447

World Bank (2019). International migration data. Available at: https://data.worldbank.org/indicator/sm.pop.totl.zs

Yazgan, P., Utku, D. E., \& Sirkeci, I. (2015). Syrian crisis and migration. Migration Letters, 12(3), 181-192. https://doi.org/10.33182/ ml.v12i3.273

Zaiceva, A., \& Zimmermann, K. F. (2008). Scale, diversity, and determinants of labour migration in Europe. Oxford Review of Economic Policy, 24(3), 427-451. https://doi.org/10.1093/oxrep/grn028

Short biographical note about the contributors at the end of the article (name, surname, academic title and scientific degree, duties, research interests):

Inna GRYSHOVA is the Doctor of Economic Sciences, professor. She is a Visiting Professor at the Jiangsu Normal University, Jiangsu Sheng, China. In addition, she works at the Institute of Legislation of the Verkhovna Rada of Ukraine. She is an author of numerous paper and reports in the journals indexed in Web of Science. Research interests: international migration; social policy; sustainability; legal studies.

Boris KOFMAN is a Chief Scientific Advisor and a Professor at the Institute of Legislation of the Verkhovna Rada of Ukraine. He is also a Honoured Lawyer of Ukraine and a distinguished scientist with many publications. Research interests: law; labour law; economic sciences; labour market; regional development.

ORCID ID: orcid.org/0000-0001-8965-2314

Olga PETRENKO is a Candiate of Economic Sciences and an Associate Professor at the Department of Economic theory and Economics of Enterprises at the Odessa State Agrarian University. Research interests: entrepreneurship; small and medium enterprises; microeconomics; labour economics.

ORCID ID: orcid.org/0000-0001-9722-3785

Register for an ORCID ID: https://orcid.org/register 